Michą PAWŁOWSKI*

\title{
NEOPOPPEROWSKI ARGUMENT PRZECIW FUNKCJONALIZMOWI ${ }^{1}$
}

\begin{abstract}
A NEO-POPPERIAN ARGUMENT AGAINST FUNCTIONALISM

This article presents a new argument against mind-body functionalism, strongly inspired by some remarks made by Karl Popper. First, the author presents the original Popperian argument against materialism (from The Self and Its Brain) and its reconstruction by Mariusz Grygianiec. The argument's conclusion is that if materialism is true, it must also be devoid of any rational grounding. Employing Ned Block's and Joseph Levine's accounts of functionalism, the author reformulates the original objection in order to make it a threat to functionalism, which is a more widespread view than the identity theory (which was the aim of Popper's criticism). The argument proves to be resilient to some potential dangers: Hilary Putnam's example of the Twin Earth or a duplicate counter-argument mentioned by Block. The conclusion is analogous to the original one: functionalism, provided that it is true, is irrational.
\end{abstract}

Keywords: functionalism, Karl Popper, mind-body problem, materialism

W artykule Mariusza Grygiańca (2016) można znaleźć interesującą rekonstrukcję dwóch Popperowskich argumentów przeciwko stanowisku materialistycznemu w kwestii problemu umysł-ciało. Pierwszy z nich prowadzi do konkluzji, że materializm, jeśli jest prawdziwy, pozbawiony jest racjonalnego uzasadnienia, drugi natomiast stwierdza, że niemożliwe jest czysto fizykalistyczne wyjaśnienie zjawiska intencjonalności.

Moim celem jest przeformułowanie pierwszego zarzutu, pierwotnie wyrażonego w napisanym przez Poppera wspólnie z Johnem C. Ecclesem tekście

* Instytut Filozofii, Uniwersytet Warszawski, ul. Krakowskie Przedmieście 3, oo-927 Warszawa, e-mail: michal.andrzej.pawlowski@gmail.com.

${ }^{1}$ Za wszelkie uwagi dotyczące tekstu (w tym szczególnie za sugestie dotyczące możliwych obiekcji względem argumentu) chciałbym serdecznie podziękować dr. hab. Mariuszowi Grygiańcowi. 
The Self and Its Brain (Popper, Eccles 1983). Zarówno oryginalny argument, jak i ten zrekonstruowany przez Grygiańca odnosił się do teorii identyczności, w przedstawionej przeze mnie wersji ma on stanowić zagrożenie dla funkcjonalizmu.

\section{POPPEROWSKA KRYTYKA TEORII IDENTYCZNOŚCI}

Popper wymienia teorię identyczności jako jedno z czterech podstawowych stanowisk materialistycznych, obok radykalnego materializmu/behawioryzmu (eliminatywizmu), epifenomenalizmu i paralelizmu (Popper, Eccles 1983: 55)². Wśród licznych mniej lub bardziej istotnych zarzutów wobec materializmu, a także umieszczanych gdzieniegdzie niezobowiązujących uwag3, pod koniec rozdziału pierwszego autorzy przywołują argument J. B. S. Haldane’a przeciwko materializmowi. Brzmi on następująco:

jeśli materializm jest prawdziwy, zdaje mi się, że nie możemy być pewni, że rzeczywiście jest on prawdziwy. Jeśli moje opinie są wynikiem chemicznych procesów zachodzących w moim mózgu, to są one determinowane przez prawa chemii, a nie logiki (cyt. za Popper, Eccles 1983: 75).

Jak Popper zauważa, bardzo łatwo odeprzeć ten zarzut ze względu na istnienie komputerów, których funkcjonowanie na podstawie praw fizyki w żaden sposób nie wyklucza działania zgodnego z prawami logiki. Następnie jednak $\mathrm{w}$ formie dialogu interakcjonisty i fizykalisty rozwija ten argument, zmierzając do wniosku, że fizykalista pozbawiony jest przy ocenie swoich przekonań zewnętrznego punktu odniesienia, którym dla interakcjonisty są obiekty Świata 3 (takie jak np. logika jako całość). Tym samym jego stanowisko jest nie do pogodzenia z racjonalizmem (Popper, Eccles 1983: 81).

Grygianiec zbiera te nieco rozproszone refleksje w jednorodną całość stanowiącą niesformulowany explicite $\mathrm{w}$ tekście Poppera argument przeciw materializmowi. Wstępnym założeniem, zgodnie z rekonstrukcją zaproponowaną przez Grygiańca (2016: 105), jest przekonanie, że język, obok funkcji ekspresyjnej i informacyjnej, pełni także funkcje komunikacyjną i argumen-

\footnotetext{
${ }^{2}$ Według Poppera epifenomenalizm i paralelizm są również formami materializmu ze względu na przyjmowanie założenia o fizycznym domknięciu Świata 1 (Popper, Eccles 1983: 51-55).

3 Jak na przykład ta: „radykalny fizykalista musi zastosować swój radykalny behawioryzm także w stosunku do siebie: jego teoria, wiara w nią, jest niczym; tylko fizyczna ekspresja w słowach i być może w argumentach - jego zachowanie werbalne i stany dyspozycyjne, które do niego doprowadziły - jest czymś” (Popper, Eccles 1983: 60).
} 
tacyjną. Dzięki nim możemy przypisywać różnym elementom języka cechy, takie jak prawdziwość, stopień uzasadnienia, materialna czy formalna poprawność przeprowadzonych wnioskowań. Zdaniem Poppera jest to bardzo niekontrowersyjne stanowisko, oczywiste dla każdego racjonalisty. Argument stanowi złożony sylogizm (Grygianiec 2016: 105-107):

1. Jeśli materializm jest prawdziwy, to każdy stan mentalny (m.in. każde przekonanie) jest identyczny z jakimś stanem neurofizycznym.

2. Jeśli każde przekonanie jest identyczne z jakimś stanem neurofizycznym, to każde wnioskowanie sprowadza się do przechodzenia $\mathrm{z}$ jednego fizycznego stanu mózgu do innego zgodnie z określonymi związkami przyczynowymi (prawami).

3. Jeśli każde wnioskowanie sprowadza się do przechodzenia $\mathrm{z}$ jednego fizycznego stanu mózgu do innego zgodnie z określonymi związkami przyczynowymi, to stany te mają moce przyczynowe wyłącznie ze względu na swoje cechy fizyczne (a nie ze względu na znaczenia czy treści, z którymi są związane).

4. Jeśli stany te mają moce przyczynowe wyłącznie ze względu na swoje cechy fizyczne, to nie istnieje pośród przekonań żadne takie, które by mogło służyć za uzasadnienie jakiegoś innego (ponieważ tylko neuronalne, przyczynowe związki określają, które przekonanie pociągane jest przez które).

5. Jeśli nie istnieje pośród przekonań żadne takie, które by mogło służyć za uzasadnienie jakiegoś innego, to żadne przekonanie nie może być racjonalnie uzasadnione.

6. Jeśli żadne przekonanie nie może być racjonalnie uzasadnione, to także materializm nie może być racjonalnie uzasadniony.

7. Wniosek: jeśli materializm jest prawdziwy, to nie może zostać racjonalnie uzasadniony.

8. Wniosek: materializm nie jest prawdziwy lub nie może być racjonalnie uzasadniony.

Grygianiec zwraca uwagę na kilka ważnych kwestii. Po pierwsze, wniosek tego rozumowania nie głosi, że materializm jest fałszywy, a jedynie że jeśli jest prawdziwy, to nie jest racjonalnie uzasadniony (Grygianiec 2016: 107108). Materialista może zgodzić się ze wszystkimi przesłankami oraz wnioskowaniami zawartymi w argumencie i po prostu przyznać, że jego stanowisko nie jest racjonalnie uzasadnione. 
Warto zauważyć, że podobne do pewnego stopnia myśli można znaleźć i u innych autorów, którzy jednak ich nie rozwijają, przechodząc do innych problemów. Jaegwon Kim zauważa, że syntaktycyzm ma problem z możliwością efektywnego przyczynowo oddziaływania własności relacyjnych (Kim 2002: 48) oraz że konsekwencją argumentu z superweniencji jest dylemat: zarówno jeśli superweniencja nie zachodzi, jak i wtedy, gdy zachodzi, przyczynowanie mentalne jest niezrozumiałe (Kim 2002: 57). Znacznie dalej idzie Uwe Meixner, twierdząc, że fizykalista może utrzymać swoje stanowisko tylko pod warunkiem, że osłabi je na tyle, że będzie ono kompatybilne z dualizmem lub też gdy będzie bronił go na tyle żarliwie, że wszelkie te zabiegi przestaną jawić się jako racjonalne (Meixner 2014: 17-19).

Popperowski argument w wersji zaproponowanej przez Grygiańca może wnieść powiew świeżości do debaty w ramach filozofii umysłu ze względu na swój interesujący i nowatorski kształt. Próba wykazania, że prawdziwość materializmu niesie ze sobą konsekwencję braku jego racjonalnego uzasadnienia, jest ciekawym pomysłem nienawiązującym do zarzutów najczęściej stosowanych przez przeciwników materializmu: Kartezjańskiego argumentu modalnego, Kripke'owskiego z identyczności czy z jedności świadomości (lub niezłożoności osób). Jego pewnym mankamentem - nie teoretycznym, lecz funkcjonalnym - jest fakt, że uderza on wyłącznie w teorię identyczności. Ta natomiast, nadwerężona przez głośne kontrargumenty Putnama z wielorakiej realizowalności czy Donalda Davidsona z anomalnego charakteru sfery mentalnej (Kim 2002: 11)4, a także przez wspomnianą krytykę Saula Kripkego (2001), znacznie straciła na popularności wśród materialistów. W tej sytuacji argument mimo swojej nowatorskiej formuły (nawet przy założeniu jego pełnej materialnej i formalnej poprawności) może nie znaleźć dużego odzewu. Aby poza tym, że stanowi interesującą kwestię historyczną, wniósł coś nowego do dyskusji nad problemem umysł-ciało, powinien stanowić zagrożenie dla jednego z popularniejszych obecnie stanowisk materialistycznych, na przykład dla funkcjonalizmu. A żeby było to możliwe, konieczne jest jego przeformułowanie.

\section{ARGUMENT PRZECIW FUNKCJONALIZMOWI}

W tekście Troubles with Functionalism Ned Block podaje przykład formalnej struktury możliwego kompletnego opisu pewnego stanu mentalnego

\footnotetext{
${ }^{4}$ Notabene, propozycja Davidsona też może być uważana za pewną wersję teorii identyczności, tyle że egzemplarzy, a nie typów.
} 
jako stanu funkcjonalnego (Block 1993: 236-237). Ogólna formuła będzie miała postać:

$$
T\left(S_{1}, \ldots, S_{n}, I_{1}, \ldots, I_{k}, O_{1}, \ldots, O_{m}\right),
$$

gdzie $T$ jest teorią psychologiczną opisującą mechanizm przejścia danego systemu ze stanu $S_{i}$ do stanu $S_{i+1}$ po otrzymaniu sygnału wejścia $I_{i}$ i kończącego się emisją wyjścia $O_{i}$. Po zastąpieniu stałych zmiennymi przebiegającymi dziedzinę obserwowalną otrzyma się zdanie ramseyowskie o postaci:

$$
\exists F_{1} \ldots \exists F_{n} T\left(S_{1}, \ldots, S_{n}, I_{1}, \ldots, I_{k}, O_{1}, \ldots, O_{m}\right) .
$$

Według Blocka jeśli predykat „odczuwać ból” lub „boleć” zastąpimy zmienną, powiedzmy $F_{17}$, to definicja bólu będzie wyglądała następująco:

$$
x \text {-a boli } \leftrightarrow\left[\exists F_{1} \ldots \exists F_{n} T\left(S_{1}, \ldots, S_{n}, I_{1}, \ldots, I_{k}, O_{1}, \ldots, O_{m}\right) \wedge x m a F_{17}\right] .
$$

W dużym uproszczeniu, jeśli przyjąć, że $T$ jest teorią opisującą ból jako stan wywoływany przez zranienie skóry oraz powodujący stan przygnębienia, a także emisję odgłosu „au!”, a z kolei stan przygnębienia jest przyczyną zmarszczenia brwi, to taka okrojona definicja będzie wyglądać następująco: $x$ - $a$ boli ( $x$ odczuwa ból, $x$ jest w stanie bólu) wtedy i tylko wtedy, gdy istnieją dwa takie stany (własności), że pierwszy z nich wywoływany jest przez zranienie skóry i powoduje emisję odgłosu „au!” oraz przejście do drugiego stanu, a drugi stan z kolei powoduje zmarszczenie brwi, oraz $x$ znajduje się w pierwszym stanie (Block 1993: 236-237). Choć doprecyzowanie to może sprawiać wrażenie błędnego koła („boli” zostaje zastąpione przez „, $F_{17} ”$, a później za pomocą $F_{17}$ definiuje się stan bólu), jest ono logicznie poprawne: $F_{17}$ stanowi pewną zmienną, która zastąpiła stan bólu, jednakże w definiensie pojawia się już nie zmienna, a pewien określony (dzięki kwantyfikatorowi egzystencjalnemu) stan funkcjonalny opisany za pomocą wyjść i wejść. W ten sposób, jak pisze Block, funkcjonalny ramseyowski korelat bólu zdefiniowany jest nie za pomocą stanów mentalnych, lecz wejść i wyjść (Block 1993: 236-237).

Przy tak sformułowanym opisie można utożsamić bycie $\mathrm{w}$ stanie bólu $\mathrm{z}$ byciem $\mathrm{w}$ jakimś $\mathrm{w}$ ten sposób opisanym stanie funkcjonalnym, co też czyni Joseph Levine w artykule Materialism and Qualia: The Explanatory Gap (1983: 355). Służy mu to do wykazania podatności funkcjonalizmu na krytykę Kripkego. Jak zauważa jednak, w ostateczności nic nie stoi na przeszkodzie, by w sytuacji, gdy nie będzie innej możliwości, funkcjonalista zgodził się, że wskazane przykłady zdań identycznościowych są koniecznie prawdziwe. Levine zmierza do udowodnienia bezzasadności materializmu nawet po przyjęciu owej koniecznej identyczności. Tutaj jednak powołuję się na niego po to, by móc swobodnie mówić o identyczności między byciem $\mathrm{w}$ danym 
stanie mentalnym a byciem w odpowiadającym mu stanie funkcjonalnym bez kłopotania się o związane z tym problemy modalne. Popperowski argument można wtedy zmodyfikować w następujący sposób:

1. Jeśli funkcjonalizm jest prawdziwy, to każdy stan mentalny (m.in. wszystkie przekonania) jest identyczny z jakimś stanem funkcjonalnym.

2. Jeśli każde przekonanie jest identyczne $\mathrm{z}$ jakimś stanem funkcjonalnym, to każde wnioskowanie sprowadza się do przechodzenia $\mathrm{z}$ jednego funkcjonalnego stanu systemu do innego zgodnie z określonymi związkami przyczynowymi (prawami) łączącymi wejścia i wyjścia systemu, opisywanymi przez daną teorię $\mathrm{T}$.

3. Jeśli każde wnioskowanie sprowadza się do przechodzenia $\mathrm{z}$ jednego funkcjonalnego stanu systemu do innego zgodnie z określonymi związkami przyczynowymi łączącymi wejścia i wyjścia systemu, opisywanymi przez daną teorię $\mathrm{T}$, to stany te mają moce przyczynowe wyłącznie ze względu na swoje cechy funkcjonalne (a nie znaczenia czy treści, z którymi są związane) przypisywane im na gruncie tej teorii.

4. Jeśli stany te mają moce przyczynowe wyłącznie ze względu na swoje cechy funkcjonalne przypisywane im na gruncie tej teorii, to nie istnieje pośród przekonań żadne takie, które mogłoby służyć za uzasadnienie jakiegoś innego (skoro tylko funkcjonalne związki przyczynowe łączące wejścia i wyjścia określają, które przekonanie pociągane jest przez które).

5. Jeśli nie istnieje pośród przekonań żadne takie, które by mogło służyć za uzasadnienie jakiegoś innego, to żadne przekonanie nie może być racjonalnie uzasadnione.

6. Jeśli żadne przekonanie nie może być racjonalnie uzasadnione, to także funkcjonalizm nie może być racjonalnie uzasadniony.

7. Wniosek: jeśli funkcjonalizm jest prawdziwy, to nie może on zostać racjonalnie uzasadniony.

8. Wniosek: funkcjonalizm nie jest prawdziwy lub nie może być racjonalnie uzasadniony5.

5 Warto zauważyć, że analogiczny argument można sformułować pod adresem epifenomenalizmu. Wychodząc od twierdzenia o braku mocy przyczynowych stanów mentalnych oraz ich charakterze jako „produktów ubocznych” stanów neurofizjologicznych, trzeba przyjąć również, że wszelkie przejścia między przekonaniami opierają się wyłącznie na tych fizycznych własnościach. W konsekwencji szybko to prowadzi do wniosku, że prawdziwość 
Niektóre spośród przesłanek tego argumentu domagają się wyjaśnienia. Przesłanka 1 jest zbieżna ze stanowiskiem funkcjonalistycznym $\mathrm{w}$ formie podanej przez Levine'a. Block czyni jednak zastrzeżenie, że mowa powinna być wyłącznie o „wąskich” stanach mentalnych (Block 1993: 237-238), tzn. takich, których warunki prawdziwościowe znajdują się niejako „wewnątrz” danej osoby. Zastrzeżenie to ma służyć uniknięciu krytyki wynikającej z przykładu Putnama dotyczącego bliźniaczej Ziemi i wody (Putnam 1993) lub też kontrprzykładu sformułowanego przez Blocka, zgodnie z którym mój stworzony przez wymianę każdej komórki duplikat będzie funkcjonalnie identyczny ze mną, nie mając jednak np. moich wspomnień. W takim wypadku prawdopodobnie należałoby odrzucić tę część przesłanki, zgodnie z którą także przekonania są identyczne z pewnymi stanami funkcjonalnymi (co najwyżej można by zgodzić się odnośnie do niektórych). Skutkiem tego jednak byłaby niemożliwość przeformułowania argumentu w zamierzony sposób. W odpowiedzi na przykłady Putnama z Ziemią bliźniaczą można jednak wskazać, że po prostu świat, w którym woda to $\mathrm{H}_{2} \mathrm{O}$, różni się w ramach danego (identycznego) systemu funkcjonalnego „wejściem” od świata, w którym woda to XYZ. Nawet jeśli te przekonania tworzą te same „wyjścia”, to będą innymi stanami funkcjonalnymi, ponieważ „wejścia” są de facto inne. Przykład z dokładnym duplikatem można natomiast swobodnie odrzucić, ponieważ nie jest wcale pewne, że mojego klona nie charakteryzowałaby ciągłość psychologiczna ze mną i że tym samym nie żywiłby takich samych przekonań co ja. Derek Parfit twierdził na przykład, że tak właśnie by było (Parfit 1984: 239).

Przesłanka 2 wynika natomiast $\mathrm{z}$ przedstawionej ogólnej formy opisu funkcjonalistycznego. Dana teoria $T T\left(S_{1}, \ldots, S_{n}, I_{1}, \ldots, I_{k}, O_{1}, \ldots, O_{m}\right)$ przewiduje wszystkie mechanizmy, za pomocą których pod wpływem impulsu ze strony wejścia i emisji wyjścia następuje przejście z jednego stanu do drugiego. Zmiana jednego stanu funkcjonalnego na drugi (czyli w szczególnym przypadku przejście z jednego przekonania do drugiego) następuje na mocy tych właśnie praw.

Funkcjonalista mógłby uchylać się od przyjęcia przesłanki 2, twierdząc, że utożsamienie wnioskowań z przechodzeniem z jednego stanu mentalnego do innego stanowi nadmierną psychologizację jego stanowiska. Skuteczną odpowiedzią na taki kontrargument powinno być jednak spostrzeżenie, że każda realizacja takiego schematu rozumowania (możliwego do zapisania jako ciąg formuł in abstracto) wymaga na gruncie funkcjonalizmu wystąpienia określonych stanów funkcjonalnych. Próba zmiany zapisu określonych elementów wniosko-

epifenomenalizmu implikuje brak jego racjonalnego uzasadnienia. W przypadku tego stanowiska jest to jednak o tyle jaśniejsze, że jego zwolennicy już na początku się godzą, że stany mentalne nie pełnią w zasadzie żadnej istotnej funkcji (por. Jackson 1982). 
wania na bardziej bezosobowe i normatywne, np. formul , $p \rightarrow q$ ” oraz , $p$ ” (prowadzących łącznie do wniosku $q$ ) na „mam prawo przejść od $p$ do $q$ ” i „mam $p$ ” (a więc „mam $q$ ”) nie ułatwi sytuacji, ponieważ cały czas wszystkie tego typu przekonania (jak tutaj „mam $p$ ”) będą pewnymi stanami funkcjonalnymi.

Jeżeli zaś funkcjonalista odpowiednio zmodyfikuje swoją odpowiedź, twierdząc, że tak skonstruowana przesłanka $2 \mathrm{w}$ nieuprawniony sposób utożsamia wnioskowanie z uzasadnieniem (co podważałoby przy okazji przesłankę 4), będzie należało przyznać mu rację, ale tylko pod warunkiem, że wskaże, jak inaczej stanowisko to mogłoby być uzasadnione - nie w sposób pośredni poprzez wnioskowanie. Czysto hipotetycznie taką racją mogłaby być przykładowo konstatacja empiryczna, jednak w przypadku dyskusji nad racjonalnym uzasadnieniem funkcjonalizmu nie wydaje się to poważną propozycją. Tutaj argument rzeczywiście ogranicza się do przypadków, w których uzasadnienie ma charakter pośredni, przez wnioskowanie, ale nie widzę przy omawianiu tego problemu żadnego innego potencjalnie wiążącego sposobu uzasadnienia.

Wytłumaczywszy przesłankę drugą, można jasno przedstawić także przesłankę 3: nie jest ważne, jakie znaczenia czy treści są związane z danym przekonaniem, a wyłącznie jaką funkcjonalną rolę opisaną przez te mechanizmy odgrywa. Podobnie rzecz się ma z przesłanką 4. Funkcjonalista mógłby ją co prawda próbować odrzucić, postulując pewnego rodzaju paralelizm między związkami przyczynowymi stanów funkcjonalnych a łańcuchem relacji łączących ich treści (np. na zasadzie relacji logicznych), nie wydaje się to jednak groźną ripostą. Albo taki paralelizm będzie pozbawiony jakichkolwiek relacji między obydwoma łańcuchami i w ten sposób de facto przestanie być fizykalizmem ${ }^{6}$, albo też będą zachodziły między nimi pewne związki, co doprowadzi do trudności opisywanych przez Kima (2002) w odniesieniu do superweniencji (takich jak np. problem przyczynowego wykluczenia). Przesłanki 5. i 6. stanowią natomiast proste tautologie.

Popperowski argument przeciwko materializmowi daje się więc przeformułować w taki sposób, by stanowił zagrożenie również dla funkcjonalizmu. $\mathrm{W}$ przekształconym argumencie zasadnicza i najbardziej kontrowersyjna zdaje się przesłanka 1. Jednak jeśli funkcjonalizm ma ambicje bycia teorią w zupełności wyjaśniającą problem umyst-ciało, to nie powinien rezygnować ze stanowiska, zgodnie z którym wszystkie (a nie wyłącznie wybrane) stany mentalne są identyczne z pewnymi stanami funkcjonalnymi. Wskazane przez Blocka trudności dają się odeprzeć przez funkcjonalistę w inny sposób, narażając go jednak tym samym na pewną wersję argumentu Poppera.

\footnotetext{
${ }^{6}$ Czyli otrzymamy, podobnie jak u Meixnera, taki „fizykalizm”, który będzie w zasadzie zbieżny z dualizmem.
} 


\section{PODSUMOWANIE}

Moim celem było wykazanie, że zaproponowana przez Poppera, a zrekonstruowana przez Grygiańca krytyka materializmu odnosi się nie tylko do teorii identyczności, ale przy pewnym przekształceniu pozostaje ważna także w kontekście znacznie bardziej dziś doniosłego intelektualnie funkcjonalizmu. W tym celu wykorzystałem przede wszystkim ujęcie Blocka oraz Levine'a. Argument ten, mimo podobieństwa do wcześniej formułowanych uwag Meixnera czy Kima, zdaje się stanowić pewne novum i tym samym może przyczynić się do ożywienia debaty nad problemem relacji umysłu i ciała. Zarazem należy jeszcze raz podkreślić, że jego wynikiem niekoniecznie musi być wniosek, że funkcjonalizm jest fałszywy. Funkcjonalista może podtrzymywać swoje stanowisko - ale tylko pod warunkiem uznania jego irracjonalności. Chęć utrzymania racjonalnych przekonań wymaga natomiast porzucenia funkcjonalizmu.

Tym samym do różnych zarzutów formułowanych pod adresem funkcjonalizmu - z odwróconego spektrum barw (ignorowanie qualiów) lub niemożliwości jednoczesnego wykluczenia zarówno liberalizmu, jak i szowinizmu (Block 1993)7 - można dodać jeszcze jeden, czyli z braku racjonalnego uzasadnienia.

\section{BIBLIOGRAFIA}

Block N. (1993), Troubles with Functionalism [w:] Readings in the Philosophy of Science, A. I. Goldman (ed.), Cambridge, MA: MIT Press, 231-253.

Grygianiec M. (2016), Die popperschen Herausforderungen für den Materialismus, „Logos i Ethos” 42(2), 103-115. http://dx.doi.org/10.15633/lie.1916

Jackson F. (1982), Epiphenomenal Qualia, „The Philosophical Quarterly” 32(12), 127-136. https://doi.org/10.2307/2960077

Kim J. (2002), Umyst w świecie fizycznym. Esej na temat problemu umystu i ciała oraz przyczynowania mentalnego, tłum. R. Poczobut, Warszawa: IFiS PAN.

7 Przez „liberalizm” rozumie Block przypisywanie stanów mentalnych takim obiektom funkcjonalnym, które w rzeczywistości na to „nie zasługują", np. populacji Chin hipotetycznie wykonującej w odpowiedni sposób poszczególne funkcje neurofizjologiczne. Próba wykluczenia tego typu przypadków skutkuje jego zdaniem ściślejszym związaniem funkcjonalizmu z naszym naturalistycznym aparatem i tym samym prowadzi do szowinizmu, czyli arbitralnej odmowy przypisania stanów mentalnych pewnym organizmom, np. zbudowanym z zupełnie innego rodzaju materii istotom myślącym, opisywanym za pomocą nieznanych nam teorii naukowych (o istnieniu takich istot rzecz jasna nie wiemy, ale nie można go a priori wykluczyć). 
Kripke S. (2001), Nazywanie a konieczność, tłum. B. Chwedeńczuk, Warszawa: Fundacja Aletheia.

Levine J. (1983), Materialism and Qualia: The Explanatory Gap, „Pacific Philosophical Quarterly" 64(4), 354-361. https://doi.org/10.1111/j.1468-0114.1983.tbo0207.x

Meixner U. (2014), Against Materialism [w:] Contemporary Dualism: A Defense, A. Lavazza, H. Robinson (ed.), London: Routledge, 17-34.

Parfit D. (1984), Reasons and Persons, Oxford: Clarendon Press.

Popper K. R., Eccles J. C. (1983), The Self and Its Brain, London: Routledge \& Kegan Paul.

Putnam H. (1993), Znaczenie i referencja, tłum. T. Szubka [w:] Filozofia języka, B. Stanosz (red.), Warszawa: Fundacja Aletheia - Wydawnictwo Spacja, 246-257. 